\title{
Plant Growth-Promoting Rhizobacteria Enhance Salinity Stress Tolerance in Okra through ROS-Scavenging Enzymes
}

\author{
Sheikh Hasna Habib, ${ }^{1,2}$ Hossain Kausar, ${ }^{3,4}$ and Halimi Mohd Saud ${ }^{1}$ \\ ${ }^{1}$ Department of Agricultural Technology, Faculty of Agriculture, Universiti Putra Malaysia, 43400 Serdang, Selangor, Malaysia \\ ${ }^{2}$ Oilseed Research Centre, Bangladesh Agricultural Research Institute (BARI), Gazipur 1701, Bangladesh \\ ${ }^{3}$ Laboratory of Food Crops, Institute of Tropical Agriculture, Faculty of Agriculture, Universiti Putra Malaysia, \\ 43400 Serdang, Selangor, Malaysia \\ ${ }^{4}$ Department of Agroforestry and Environmental Science, Sher-E-Bangla Agricultural University, Dhaka, Bangladesh \\ Correspondence should be addressed to Halimi Mohd Saud; halimi@upm.edu.my
}

Received 10 September 2015; Revised 29 December 2015; Accepted 30 December 2015

Academic Editor: Qaisar Mahmood

Copyright (C) 2016 Sheikh Hasna Habib et al. This is an open access article distributed under the Creative Commons Attribution License, which permits unrestricted use, distribution, and reproduction in any medium, provided the original work is properly cited.

Salinity is a major environmental stress that limits crop production worldwide. In this study, we characterized plant growthpromoting rhizobacteria (PGPR) containing 1-aminocyclopropane-1-carboxylate (ACC) deaminase and examined their effect on salinity stress tolerance in okra through the induction of ROS-scavenging enzyme activity. PGPR inoculated okra plants exhibited higher germination percentage, growth parameters, and chlorophyll content than control plants. Increased antioxidant enzyme activities (SOD, APX, and CAT) and upregulation of ROS pathway genes (CAT, APX, GR, and DHAR) were observed in PGPR inoculated okra plants under salinity stress. With some exceptions, inoculation with Enterobacter sp. UPMR18 had a significant influence on all tested parameters under salt stress, as compared to other treatments. Thus, the ACC deaminase-containing PGPR isolate Enterobacter sp. UPMR18 could be an effective bioresource for enhancing salt tolerance and growth of okra plants under salinity stress.

\section{Introduction}

Soil salinity is a major problem in agriculture that limits plant growth and causes significant loss of crop productivity worldwide $[1,2]$. Salinity affects up to $20 \%$ and $50 \%$ of the total cultivated and irrigated land in the world, respectively [3]. However, the use of saline water in agriculture is gradually increasing owing to shortage of fresh water. Consequently, on one hand, salt-affected areas are constantly increasing, and, on the other hand, a significant amount of arable land is being abandoned every year because of salinity [4].

Okra (Abelmoschus esculentus L.) is an annual vegetable crop cultivated in tropical and subtropical regions. It is considered a high-value vegetable crop owing to its high levels of vitamins, minerals, carbohydrates, and fats [5]. Although it has good nutritional value as well as high consumer demand, the yield of okra per hectare is very low, and this lower productivity arises mainly from soil salinity.
Salt deposits in the crop field are a result of the use of saline underground irrigation water. Discharge of industrial effluents into irrigation canals is also a potential source of salts in agricultural soil. Saline water reduces the transpiration rate of plants by disrupting the evapotranspiration system thus reducing crop yield [6]. A high percentage of salt in the root zone affects root density, root turgor pressure, and water absorption, which eventually affects plant growth and development. The okra plant is sensitive to salinity especially in the early stage of its growth [7] where salinity affects water and nutrient uptake of the plant, and ionic stress reduces leaf expansion. Altered morphological traits in the canola plant [8], reduced plant dry matter and leaf area in soybeans [9], and reduced yield of canola [10] due to salinity have been reported. In the root zone, high salt concentration decreases soil water potential and water availability, which causes dehydration at the cellular level, eventually leading to osmotic stress [11]. 
Salinity stress generates reactive oxygen species (ROS), namely, $\mathrm{H}_{2} \mathrm{O}_{2}, \mathrm{O}^{-2}$, and $\mathrm{OH}^{-}$that damage the DNA, RNA, and proteins $[12,13]$. These ROS compounds also cause chlorophyll destruction and damage the root meristem activity [14]. Antioxidant enzymes such as superoxide dismutase (SOD), catalase (CAT), and ascorbate peroxidase (APX) have the ability to scavenge the ROS and maintain them at low levels. Superoxide dismutase is a metalloenzyme that plays an important role in protecting cells from oxidative damage, by catalyzing the conversion of the superoxide radical to $\mathrm{H}_{2} \mathrm{O}_{2}$ $[15,16]$. Ascorbate peroxidase has vital defensive role against ROS [17] and can catalyze the breakdown of $\mathrm{H}_{2} \mathrm{O}_{2}$ that is produced by SOD. Catalase reduces ROS levels by catalyzing the breakdown of $\mathrm{H}_{2} \mathrm{O}_{2}$ into $\mathrm{H}_{2} \mathrm{O}$ and $\mathrm{O}_{2}[12,13]$.

Genetic engineering is an attractive approach that can generate plants resistant to salt stress [18]. AtNHX1 overexpressing transgenic Brassica napus plants were found to grow, flower, and produce seeds under $200 \mathrm{mM}$ salt stress [19]. However, the transgenic approach is time-consuming and expensive. ACC deaminase-containing PGPR can reduce the deleterious effects of environmental stress and can enhance stress tolerance of plants by a variety of mechanisms such as the synthesis of phytohormones, mineral solubilization, nutrient uptake, increased leaf area, increased chlorophyll and soluble protein content, and antioxidant enzyme activities [20]. Ethylene is important for plant growth and development, as well as in the fruit ripening process, but an excess amount of ethylene might decrease seed germination and root growth $[21,22]$. It is also reported that ethylene production increases under stress conditions and results in inhibitory effects on plants [23]. However, ACC deaminasecontaining PGPR can hydrolyse ACC, the precursor of ethylene, thereby reducing the excess ethylene and rescue plants from inhibitory effects [24-26].

The plant growth-promoting effects of the interactions of Pseudomonas fluorescens YsS6, P. migulae 8R6, and their ACC deaminase deficient mutants on the growth of tomato plants were investigated under $165 \mathrm{mM}$ and $185 \mathrm{mM}$ of salt stress. The plants treated with ACC deaminase-containing bacterial isolates exhibited higher fresh and dry biomass, higher chlorophyll content, and a greater number of flowers and buds than the ACC deaminase deficient bacteria and control plants [27]. Similarly, Saravanakumar and Samiyappan [22] reported that the ACC deaminase-containing $P$. fluorescens strain TDK1 increased the vigor index of groundnut seedlings significantly under $120 \mathrm{mM}$ of salt stress condition as compared to plants pretreated with a Pseudomonas strain lacking ACC deaminase activity. ACC deaminase-containing Bacillus subtilis also induced salinity stress tolerance in hydroponically grown tomato plants [28]. Bacteria containing high amounts of SOD and CAT play an important protective role against the deleterious effect of ROS under stress conditions $[16,29]$. Moreover, induction of salt stress tolerance using PGPR is an efficient and inexpensive method. However, there are very few reports on PGPR induced salinity tolerance in the okra plant caused by changes in ROS-scavenging enzymes. Therefore, in this study, we characterized the ACC deaminase-containing PGPR with respect to its effect on growth, antioxidant enzyme activities, and expression profiles of ROS pathway genes in the okra plant under high salt stress.

\section{Materials and Methods}

2.1. Source of Plant Growth-Promoting Rhizobacteria. Fifteen PGPR isolates were used in this study. All PGPR isolates were initially isolated from crop fields of the Universiti Putra Malaysia (UPM), Serdang, Selangor, and Semerak, Pasir Puteh, Kelantan, Malaysia, by using the dilution plate technique. All selected PGPR isolates possessed nitrogen fixation, phosphate solubilization, indoleacetic acid (IAA) synthesis, and salt tolerant properties [30].

\subsection{ACC Deaminase Activity of Plant Growth-Promoting} Rhizobacteria. All 15 PGPR isolates were tested for ACC deaminase activity following the method described by Jacobson et al. [31]. Bacterial isolates were grown on Nutrient Broth $\left(\mathrm{NB}, \mathrm{Difco}{ }^{\mathrm{TM}}\right)$ for $48 \mathrm{~h}$ at $28 \pm 2^{\circ} \mathrm{C}$. The cultures were diluted 10 -fold with sterile $\mathrm{MgSO}_{4}(0.1 \mathrm{M})$ solution. ACC (3 mM) was filter sterilized with $0.2 \mu \mathrm{m}$ filter membrane and stored at $-20^{\circ} \mathrm{C}$ until further use. In a 96 -well plate, $120 \mu \mathrm{L}$ of minimal salt medium (MSM) was added to each well. To the first 4 lanes, $15 \mu \mathrm{L}$ of $\mathrm{MgSO}_{4}(0.1 \mathrm{M})$ was added and, to the next 4 lanes, $15 \mu \mathrm{L}$ of $\left(\mathrm{NH}_{4}\right)_{2} \mathrm{SO}_{4}(0.1 \mathrm{M})$ was added. Thawed ACC $(15 \mu \mathrm{L})$ was added to the remaining 4 lanes. Each of the PGPR isolates $(15 \mu \mathrm{L})$ was added into each well separately. For the untreated control, $15 \mu \mathrm{L}$ of $\mathrm{MgSO}_{4}(0.1 \mathrm{M})$ was used instead of the PGPR culture. All plates were incubated for $48 \mathrm{~h}$ and the optical density (OD) was measured at $600 \mathrm{~nm}$ with the Thermo Scientific Multiskan $^{\mathrm{Tm}}$ GO microplate spectrophotometer (Thermo Fisher Scientific Inc., USA).

The OD values of ACC- and $\left(\mathrm{NH}_{4}\right)_{2} \mathrm{SO}_{4}$-containing wells were compared with the $\mathrm{MgSO}_{4}$-containing wells to determine the ability of PGPR isolates to utilize ACC for their growth. The PGPR isolates were categorized into three groups as isolates with higher, medium, and lower ACC utilizing rate depending upon the ratio of their $\mathrm{OD}$ values at $600 \mathrm{~nm}$ for ACC substrate as compared to $\left(\mathrm{NH}_{4}\right)_{2} \mathrm{SO}_{4}$. Isolates with higher ACC-utilization rate showed OD values for wells with ACC substrate close to $\mathrm{OD}$ values for wells with $\left(\mathrm{NH}_{4}\right)_{2} \mathrm{SO}_{4}$ in the initial $48 \mathrm{~h}$ of growth. Similarly, isolates with medium ACC-utilization rate showed lower OD values for ACC wells as compared to those for $\left(\mathrm{NH}_{4}\right)_{2} \mathrm{SO}_{4}$ in the initial $48 \mathrm{~h}$ of growth. Isolates with lower ACC-metabolic rate possessed the lowest OD values for ACC wells (close to OD values of wells with $\mathrm{MgSO}_{4}$ ) in the same time.

2.3. Identification of PGPR Isolates. PGPR isolates, UPMR2 and UPMR18, with the highest ACC-metabolizing activities were identified by $16 \mathrm{~S}$ rRNA gene sequencing as Bacillus megaterium and Enterobacter sp., respectively (Figure 1(a)). In brief, each PGPR isolate was grown at $28^{\circ} \mathrm{C}$ for $48-72 \mathrm{~h}$ in $5 \mathrm{~mL}$ of $\mathrm{NB}$. Of each culture, $1 \mathrm{~mL}$ was transferred into separate $1.5 \mathrm{~mL}$ microcentrifuge tubes. Bacterial cells were pelleted by centrifugation at $12000 \mathrm{~g}$ for $5 \mathrm{~min}$ (Eppendorf Centrifuge 5810 R, Hamburg, Germany). Bacterial genomic DNA was extracted with the Genomic DNA Mini Kit 


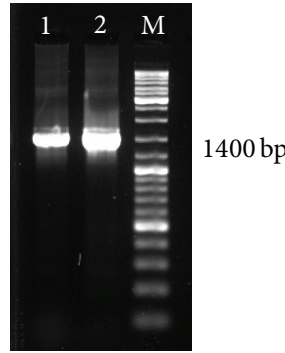

(a)

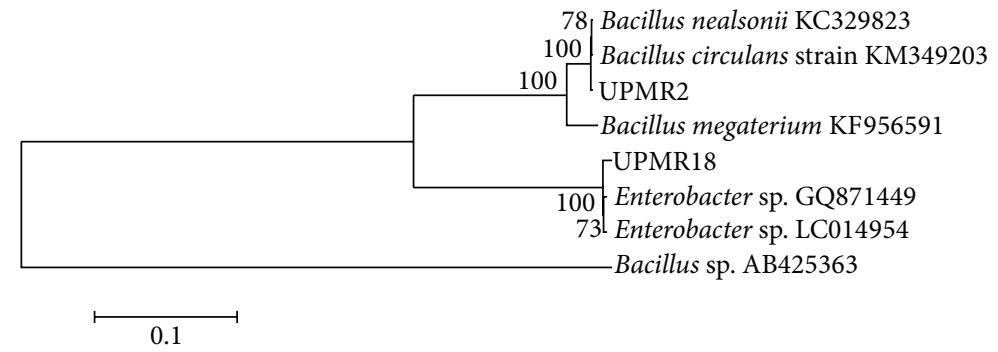

(b)

FIGURE 1: (a) Agarose gel electrophoresis of 16S rDNA PCR products of bacterial isolates. Lane M: 100 bP DNA ladder. Lanes 1 and 2: bacterial isolates UPMR2 and UPMR18. (b) The neighbor-joining tree shows the phylogenetic relationship of the isolates UPMR2 and UPMR18 with related isolates from the NCBI database.

(Yeastern Biotech Co., Ltd.) according to the manufacturer's protocol.

The universal primer pairs $27 \mathrm{f}\left(5^{\prime}\right.$-AGAGTTTGATCMTGGCTCAG- $\left.3^{\prime}\right)$ and 1492R ( $5^{\prime}$-GGTTACCTTGTTACGACTT $-3^{\prime}$ ) were used to amplify the $16 \mathrm{~S}$ rRNA coding region. The $25 \mu \mathrm{L}$ PCR reaction mixture consisted of the following components: $1 \mu \mathrm{L}$ of each extracted PGPR genomic DNA, $0.15 \mu \mathrm{M}$ of each primer, $1 \mathrm{x}$ PCR reaction buffer (Fermentas, USA), $0.2 \mathrm{mM}$ of dNTP mix, $2.5 \mathrm{U}$ of Taq polymerase (Fermentas, USA), $25 \mathrm{mM}$ of $\mathrm{MgCl}_{2}$, and nucleic acidfree water to make up final volume. The thermal cycling conditions were as follows: one cycle for $5 \mathrm{~min}$ at $94^{\circ} \mathrm{C}$, 30 cycles at $94^{\circ} \mathrm{C}$ for $30 \mathrm{sec}, 55^{\circ} \mathrm{C}$ for $30 \mathrm{sec}$, and $72^{\circ} \mathrm{C}$ for $1 \mathrm{~min}$ followed by an additional cycle at $72^{\circ} \mathrm{C}$ for $5 \mathrm{~min}$. The amplified PCR products were purified using QIAquick Gel Extraction Kit (QIAGEN Inc., USA) and sent for sequencing. The obtained sequences were analyzed and compared with sequences obtained from the GenBank database using the BLAST program to determine the percent similarity. A molecular phylogenetic tree was constructed in Mega version 4 software following the neighbor-joining method [32]. The BLASTX analysis showed that the isolates UPMR2 and UPMR18 matched with B. megaterium and Enterobacter sp., respectively, with $99 \%$ similarity. Phylogenetic analysis of the bacterial isolates was also performed on the basis of the neighborhood joining method with 100 bootstrap sampling replicates (Figure 1(b)).

\subsection{Evaluation of PGPR Isolates on Okra Seed Germination} under Salt Stress. Two PGPR isolates UPMR2 and UPMR18 were selected based on their growth promotion, halotolerance, and ACC deaminase activities and were investigated in the context of seed germination in okra under different levels of $\mathrm{NaCl}$ stress.

Seeds of the local Malaysian okra variety five anchor were used in this study. The seeds were surface sterilized with $0.5 \%(\mathrm{v} / \mathrm{v})$ sodium hypochlorite for $20 \mathrm{~min}$ followed by repetitive washes with distilled water. The seeds were then soaked in PGPR suspension $\left(10^{8} \mathrm{cfu} / \mathrm{mL}\right)$ or in distilled water (control) for $24 \mathrm{~h}$. A total of 10 seeds were sown in Petri dishes ( $9 \mathrm{~mm}$ diameter) with two sheets of Whatman number 1 filter papers. The seeds were moistened either with distilled water (control) or with solutions of varying $\mathrm{NaCl}$ concentration
$(25,50,75$, and $100 \mathrm{mM})$ and kept at $25^{\circ} \mathrm{C}$ in the dark. After three days, the emergence of the radicle from the seed was considered as an index of germination. The germination percentage was calculated as follows:

$$
\text { Germination } \%=\left(\frac{\text { No. of seeds germinated }}{\text { No. of seeds sown }}\right) \times 100 .
$$

2.5. Evaluation of PGPR Isolates on Growth Promotion of Okra under Salt Stress. Okra seeds were surface sterilized and sown in Petri dishes. After emergence of the radicle and plumule, the seedlings were planted in plastic pots (one seedling/pot) filled with sterilized soil. The soil belongs to Serdang soil series, which was sandy-loam in texture (order Ultisols). The soil contained total $\mathrm{N}(0.78 \%)$, available $\mathrm{P}$ (54.92 ppm), potassium (218 ppm), and total C (2.94\%) and had a pH of 5.32. Twenty-five milliliters of PGPR suspension $\left(10^{8} \mathrm{cfu} / \mathrm{mL}\right)$ was applied to the roots of potted okra plants at 15 days after transplantation (DAT) and 22 DAT. Control plants were treated with the same amount of water. The plants were subjected to salt stress two weeks after the second inoculation by watering with $75 \mathrm{mM}$ of $\mathrm{NaCl}$ solution. To prevent the plants from undergoing osmotic shock, $\mathrm{NaCl}$ concentration was imposed in $25 \mathrm{mM}$ increments per day until the final concentration was attained after three days [33]. The soil surface was covered with black plastic to prevent salt loss. Four treatment groups were defined as follows: T0: noninoculated salt treated plants, T1: UPMR2 inoculated salt treated plants, T2: UPMR18 inoculated salt treated plants, and T3: both UPMR2 and UPMR18 inoculated salt treated plants. Each treatment group comprised 16 plants. Plants were grown for 15 days under salt stress conditions. Growth parameters, that is, plant height, root length, fresh weight of leaf, stem, and root, and dry weight of leaf, stem, and root, were recorded at 15 days after salt treatment.

2.5.1. Leaf Chlorophyll Measurements. The total leaf chlorophyll and chlorophyll a (chla) and chlorophyll b (chlb) content and the chlorophyll $\mathrm{a} / \mathrm{b}$ ratio were determined at 15 days after salt treatment by using the method described by Moran and Porath [34]. Frozen leaflet samples of $0.2 \mathrm{~g}$ from each treatment were cut into small pieces and placed in a glass vial containing $2 \mathrm{~mL}$ of $\mathrm{N}, \mathrm{N}$-dimethylformamide 
(DMF) and were covered with aluminum foil. The vials were then incubated at $4^{\circ} \mathrm{C}$ for $48 \mathrm{~h}$. The absorbance readings of chlorophyll $\mathrm{a}$ and $\mathrm{b}$ were taken at wave lengths of $663 \mathrm{~nm}$ and $645 \mathrm{~nm}$, respectively, with a UV-visible spectrophotometer (Genesys 10 UV, Thermo Fisher Scientific, USA) using DMF as a blank. The concentrations of total chlorophyll, chla, and chlb were calculated according to the following equations [35]:

$$
\begin{aligned}
& \text { Chlorophyll } \mathrm{a}=\left(0.0127 D_{663}-0.00269 D_{645}\right), \\
& \text { Chlorophyll } \mathrm{b}=\left(0.0229 D_{645}-0.0468 D_{663}\right),
\end{aligned}
$$

Total chlorophyll $=$ Chlorophyll a + Chlorophyll b,

where $D_{663}$ is absorbance at $663 \mathrm{~nm}$ wave length and $D_{645}$ is absorbance at $645 \mathrm{~nm}$ wave length.

2.5.2. Enzymatic Assay. Leaf protein was extracted from frozen leaflet samples ground in liquid nitrogen using icecold mortar and pestle. Protein was extracted in $3 \mathrm{~mL}$ of extraction buffer containing $100 \mathrm{mM} \mathrm{K}$-phosphate buffer (pH 7.8), 0.1 mM EDTA, $14 \mathrm{mM}$ 2-mercaptoethanol, and $0.1 \%(\mathrm{v} / \mathrm{v})$ Triton X-100 for SOD (EC 1.15.1.1) activity or $50 \mathrm{mM}$ K-phosphate buffer (pH 7.0), 2 mM EDTA, $20 \mathrm{mM}$ ascorbate, and $0.1 \%(\mathrm{v} / \mathrm{v})$ Triton X-100 for CAT (EC 1.11.1.6) and APX (EC 1.11.1.11) activities. The homogenate was than centrifuged at $15000 \times \mathrm{g}$ for $15 \mathrm{~min}$ at $4^{\circ} \mathrm{C}$. The supernatant was used for total protein [36] and enzymatic assays.

SOD activity was determined according to the method described by Giannopolitis and Ries [37]. The reaction mixture contained $50 \mathrm{mM}$ K-phosphate buffer ( $\mathrm{pH} 7.8$ ), $0.1 \mathrm{mM}$ EDTA, $13 \mathrm{mM}$ methionine, $75 \mu \mathrm{M}$ nitrobluetetrazolium (NBT), $2 \mu \mathrm{M}$ riboflavin, and $100 \mu \mathrm{L}$ enzyme extract. SOD activity was determined by the ability of the enzyme to inhibit photochemical reduction of NBT on blue formazan, followed by monitoring absorbance of the reaction mixture at $560 \mathrm{~nm}$.

The total CAT activity in the leaf was assayed based on the rate of $\mathrm{H}_{2} \mathrm{O}_{2}$ consumption at $240 \mathrm{~nm}$ [38]. The assay mixture of $3 \mathrm{~mL}$ contained $100 \mathrm{mM}$ phosphate buffer ( $\mathrm{pH}$ 7.0), $0.1 \mathrm{mM}$ EDTA, $0.1 \% \mathrm{H}_{2} \mathrm{O}_{2}$, and $20 \mu \mathrm{L}$ enzyme extract. After addition of the enzyme extract to the reaction mixture, decrease in $\mathrm{H}_{2} \mathrm{O}_{2}$ levels was determined by measuring the absorbance at $240 \mathrm{~nm}$ with a UV1000 spectrophotometer and quantified by using the extinction coefficient $(36 \mathrm{M} 21 \mathrm{~cm} 21)$.

Total leaf APX activity was estimated at $290 \mathrm{~nm}$ by the method described by Chen and Asada [39]. The $3 \mathrm{~mL}$ APX assay mixture contained $50 \mathrm{mM} \mathrm{K}$-phosphate buffer $(\mathrm{pH}$ 7.0), $0.1 \mathrm{mM} \mathrm{H} \mathrm{H}_{2} \mathrm{O}_{2}, 0.5 \mathrm{mM}$ ascorbate, and $20 \mu \mathrm{L}$ enzyme extract. The amount of ascorbate oxidized was calculated using extinction coefficient $E=2.8 \mathrm{mM}^{-1} \mathrm{~cm}^{-1}$.

2.5.3. Expression of ROS Pathway Genes. Total RNA was extracted from approximately $0.1 \mathrm{~g}$ of frozen okra leaf samples using TRIzol ${ }^{\circledR}$ reagent (Invitrogen, USA). The firststrand cDNA was synthesized from $1 \mu \mathrm{g}$ of total RNA using QuantiTect ${ }^{\circledR}$ Reverse Transcription Kit (Qiagen, USA) according to the manufacturer's instructions. The expression
TABLE 1: Primer pairs used for RT-PCR in this study.

\begin{tabular}{lcc}
\hline $\begin{array}{l}\text { NCBI } \\
\text { accession } \\
\text { number }\end{array}$ & $\begin{array}{c}\text { Primer } \\
\text { name }\end{array}$ & \multicolumn{1}{c}{ Sequence $\left(5^{\prime}-3^{\prime}\right)$} \\
\hline X55749 & Actin & $\begin{array}{l}\text { F: CTGGTGGTGCAACAACCTTA } \\
\text { R: GAATGGAAGCAGCTGGAATC }\end{array}$ \\
\hline AB041343 & APX & $\begin{array}{l}\text { F: ACCAATTGGCTGGTGTTGTT } \\
\text { R: TCACAAACACGTCCCTCAAA }\end{array}$ \\
\hline AY442179 & CAT & $\begin{array}{l}\text { F: TGCCCTTCTATTGTGGTTCC } \\
\text { R: GATGAGCACACTTTGGAGGA }\end{array}$ \\
\hline X76533 & GR & $\begin{array}{l}\text { F: GGATCCTCATACGGTGGATG } \\
\text { R: TTAGGCTTCGTTGGCAAATC }\end{array}$ \\
\hline DQ512964 & DHAR & $\begin{array}{l}\text { F: AGGTGAACCCAGAAGGGAAA } \\
\text { R: TATTTTCGAGCCCACAGAGG }\end{array}$ \\
\hline
\end{tabular}

patterns of genes of the ROS pathway (APX, CAT, DHAR, and GR) were analyzed by semiquantitative RT-PCR using the primer pairs [40] mentioned in Table 1 with actin as a control.

RT-PCR was performed using aliquots of $1 \mu \mathrm{L}$ cDNA samples. The PCR conditions were set as follows: one cycle at $95^{\circ} \mathrm{C}$ for $5 \mathrm{~min}$, followed by 35 cycles at $95^{\circ} \mathrm{C}$ for $30 \mathrm{sec}, 52^{\circ} \mathrm{C}$ for $30 \mathrm{sec}$, and $72^{\circ} \mathrm{C}$ for $15 \mathrm{sec}$ followed by an additional cycle of five minutes at $72^{\circ} \mathrm{C}$. The PCR products were separated on $1.5 \%$ agarose gel and were observed under UV light.

2.6. Statistical Analysis. All experiments were conducted using completely randomized design (CRD) with four replicates. The data were subjected to analysis of variance (ANOVA) and tested for significance using the least significant difference (LSD) by PC-SAS software (SAS Institute, Cary, NC, USA, 2001).

\section{Results}

3.1. ACC Deaminase Activity. The ACC deaminase activity of the PGPR isolates was determined qualitatively to characterize the isolates for their ability to use ACC as the sole nitrogen source. The PGPR isolates were categorized into three groups, as isolates with higher $(>0.7)$, medium $(0.5-$ $0.69)$, and lower $(<0.5)$ ACC metabolism rate depending on their growth which was measured in terms of cell density at $\mathrm{OD}_{600}$ (data not shown). On the basis of their high ACC deaminase activity, two PGPR isolates B. megaterium UPMR2 and Enterobacter sp. UPMR18 were selected to assess their salt tolerance potency in okra plants.

3.2. Effect of PGPR Isolates on Germination of Okra Seeds under Salt Stress. The results showed that the germination of okra seeds was significantly $(p \leq 0.05)$ affected by the PGPR isolates under different salt concentrations (Table 2). Both the PGPR isolates either separately or in combination showed $100 \%$ seed germination up to $75 \mathrm{mM} \mathrm{NaCl}$ concentrations. Seed germination declined to $80 \%$ at $100 \mathrm{mM}$ $\mathrm{NaCl}$ concentration. On the other hand in the noninoculated group, seed germination percentage was $70 \%$ at $75 \mathrm{mM} \mathrm{NaCl}$ 
TABLE 2: Effect of PGPR inoculation on germination of okra seeds under salt stress.

\begin{tabular}{lccccc}
\hline \multirow{2}{*}{ Treatments } & \multicolumn{5}{c}{ Salinity levels } \\
& $0 \mathrm{mM}$ & $25 \mathrm{mM}$ & $50 \mathrm{mM}$ & $75 \mathrm{mM}$ & $100 \mathrm{mM}$ \\
\hline $\begin{array}{l}\text { Control } \\
\text { Bacillusmegaterium } \\
\text { (UPMR2) }\end{array}$ & 100 & 100 & 100 & $70^{\mathrm{b}}$ & $50^{\mathrm{b}}$ \\
$\begin{array}{l}\text { Enterobacter sp. } \\
\text { (UPMR18) }\end{array}$ & 100 & 100 & 100 & $100^{\mathrm{a}}$ & $80^{\mathrm{a}}$ \\
$\begin{array}{l}\text { Coinoculation of } \\
\text { UPMR2 \& UPMR18 }\end{array}$ & 100 & 100 & 100 & $100^{\mathrm{a}}$ & $80^{\mathrm{a}}$ \\
\hline
\end{tabular}

Means within columns with the same letters are not significantly different at $p<0.05$.

concentration while the lowest germination percentage (50\%) was recorded at $100 \mathrm{mM} \mathrm{NaCl}$ concentration.

\subsection{Effect of PGPR Isolates on Growth of Okra Seedlings} under Salt Stress. The effects of PGPR inoculation on okra plants were assessed at $75 \mathrm{mM} \mathrm{NaCl}$ concentration. The results demonstrate that the application of PGPR isolates B. megaterium UPMR2 and Enterobacter sp. UPMR18 significantly $(p \leq 0.05)$ increased shoot and root growth of okra as compared to noninoculated plants. Significantly ( $p \leq$ $0.05)$, the highest leaf fresh $(4.04 \mathrm{~g})$ and dry $(0.469 \mathrm{~g})$ weight were obtained in Enterobacter sp. UPMR18 (T2) treated plants compared to other treatments. As with leaf biomass, significantly $(p \leq 0.05)$ highest shoot dry weight $(0.28 \mathrm{~g})$ and root fresh weight $(0.78 \mathrm{~g})$ were also observed in the plants receiving Enterobacter sp. UPMR18 (T2) under salt stress. In addition, significantly $(p \leq 0.05)$ highest shoot fresh weight and root dry weight were recorded both in Enterobacter sp. UPMR18 (T2) treatment and in the combined application of B. megaterium UPMR2 and Enterobacter sp. UPMR18 (T3) treated plants under salinity stress conditions (Table 3 ).

3.4. Determination of Okra Leaf Chlorophyll Content. The data obtained for plant pigments showed that chlorophyll a was significantly $(p \leq 0.05)$ highest in plants treated with Enterobacter sp. UPMR18 (T2) and the combined application of both the PGPR (T3) compared to other treatments. Chlorophyll $\mathrm{b}$ and chlorophyll $\mathrm{a} / \mathrm{b}$ ratio were increased significantly $(p \leq 0.05)$ in all inoculated plants compared to noninoculated salinized plants. Similarly, all the PGPR treated plants showed significantly ( $p \leq 0.05$ ) higher values for total chlorophyll content than the control (Figure 2).

3.5. Determination of Activities of ROS-Scavenging Enzymes. All PGPR inoculated plants exhibited higher percent increase in ROS-scavenging enzymes in comparison to the noninoculated control plants (Figure 3). APX activity was significantly $(p \leq 0.05)$ highest in B. megaterium UPMR2 (T1) inoculated salinized plants where it was approximately 13 times higher than the noninoculated plants. Significantly $(p \leq 0.05)$ higher CAT activity was also observed in all PGPR inoculated plants as compared to control. CAT activity was recorded to be approximately $5.4,4.8$, and 3.4 times higher in the plants inoculated with Enterobacter sp. UPMR18 (T2), combined PGPR (T3) application, and B. megaterium UPMR2 (T1), respectively, as compared to control plants under salt stress. Similarly, the activity of SOD was also increased significantly $(p \leq 0.05)$ (approximately 2 and 1.5 times higher) in the plants inoculated with Enterobacter sp. UPMR18 (T2) and with the combined application of both PGPR (T3), compared to the noninoculated stressed plants.

3.6. Expression Analysis of ROS Pathway Genes by RT-PCR. The ROS-scavenging enzymes, CAT, SOD, and APX, were assessed in okra plants after salinity stress, after inoculation, or without inoculation with PGPR B. megaterium UPMR2 and Enterobacter sp. UPMR18. The PGPR inoculated salinized plants exhibited the maximum percent increase in ROS-scavenging enzymes with respect to the noninoculated salinized control plants. APX activity was significantly increased in B. megaterium UPMR2 inoculated salinized plants and was approximately 13 times higher than that of noninoculated salinized plants (Figure 4). Significantly increased CAT activity was also observed in all PGPR inoculated salinized plants than that of control (noninoculated salinized plants). CAT activity was recorded as approximately 3.4, 5.4, and 4.8 times higher in plants inoculated with B. megaterium UPMR2, Enterobacter sp. UPMR18, and combined application of PGPR isolates, respectively, compared to that of noninoculated plants under the same stress conditions (Figure 4). Similarly, SOD activity was also increased significantly (approximately 2 and 1.5 times higher) in plants inoculated with Enterobacter sp. UPMR18 and with combined application of PGPR, respectively, growing under stress condition compared to noninoculated salt stressed plants (Figure 4).

\section{Discussion}

Application of ACC deaminase-containing PGPR as a soil amendment resulted in enhanced seed germination, chlorophyll content, and growth of okra plants under salinity stress by maintaining low stress ethylene levels and increasing the ROS-scavenging enzymes. Ethylene, a plant growth regulator, is involved in various physiological responses [41]. However, it is regarded as a stress hormone since it is synthesized at a rapid rate under stress [42]. Stress ethylene decreases seed germination and root development and eventually hinders plant growth $[21,22]$. Microorganisms synthesizing the ACC deaminase enzyme can cleave ACC to $\alpha$-ketobutyrate and ammonia, thereby decreasing ethylene stress in plants [4345]. In this study, two PGPR B. megaterium UPMR2 and Enterobacter sp. UPMR18 that possessed characteristics of ACC deaminase activity demonstrated their effectiveness in inducing salt tolerance and consequent improvement in the growth of okra plants under salt stress.

Okra is a salt sensitive crop, especially in its early growth stage [46]. Seed germination of okra was reduced at a higher rate with increasing level of salinity in the noninoculated group (Table 2). Salinity increases the osmotic potential of growth medium and, as a result, seeds require more energy to absorb water, resulting in decreased germination 
TABLE 3: Effect of PGPR inoculation on growth attributes of okra plants under salinity stress.

\begin{tabular}{lccccrr}
\hline Treatment & $\begin{array}{c}\text { LFW/plant } \\
(\mathrm{g})\end{array}$ & $\begin{array}{c}\text { LDW/plant } \\
(\mathrm{g})\end{array}$ & $\begin{array}{c}\text { SFW/plant } \\
(\mathrm{g})\end{array}$ & $\begin{array}{c}\text { SDW/plant } \\
(\mathrm{g})\end{array}$ & $\begin{array}{c}\text { RFW/plant } \\
(\mathrm{g})\end{array}$ & $\begin{array}{c}\text { RDW/plant } \\
(\mathrm{g})\end{array}$ \\
\hline T0 & $2.63 \pm 0.13^{\mathrm{c}}$ & $0.26 \pm 0.03^{\mathrm{c}}$ & $1.57 \pm 0.14^{\mathrm{c}}$ & $0.14 \pm 0.02^{\mathrm{c}}$ & $0.34 \pm 0.03^{\mathrm{d}}$ & $0.04 \pm 0.01^{\mathrm{b}}$ \\
T1 & $2.83 \pm 0.15^{\mathrm{c}}$ & $0.28 \pm 0.03^{\mathrm{c}}$ & $1.90 \pm 0.08^{\mathrm{b}}$ & $0.16 \pm 0.02^{\mathrm{c}}$ & $0.47 \pm 0.05^{\mathrm{c}}$ & $0.03 \pm 0.00^{\mathrm{b}}$ \\
T2 & $3.92 \pm 0.17^{\mathrm{a}}$ & $0.46 \pm 0.01^{\mathrm{a}}$ & $2.56 \pm 0.29^{\mathrm{a}}$ & $0.28 \pm 0.01^{\mathrm{a}}$ & $0.79 \pm 0.08^{\mathrm{a}}$ & $0.07 \pm 0.02^{\mathrm{a}}$ \\
T3 & $3.28 \pm 0.25^{\mathrm{b}}$ & $0.37 \pm 0.01^{\mathrm{b}}$ & $2.65 \pm 0.07^{\mathrm{a}}$ & $0.22 \pm 0.01^{\mathrm{b}}$ & $0.65 \pm 0.06^{\mathrm{b}}$ & $0.06 \pm 0.00^{\mathrm{a}}$ \\
\hline
\end{tabular}

T0: noninoculated salt treated plants, T1: UPMR2 inoculated salt treated plants, T2: UPMR18 inoculated salt treated plants, and T3: UPMR2 and UPMR18 inoculated salt treated plants. LFW: leaf fresh weight, LDW: leaf dry weight, SFW: shoot fresh weight, SDW: shoot dry weight, RFW: root fresh weight, and RDW: root dry weight. Means within columns with the same letters are not significantly different at $p<0.05$.
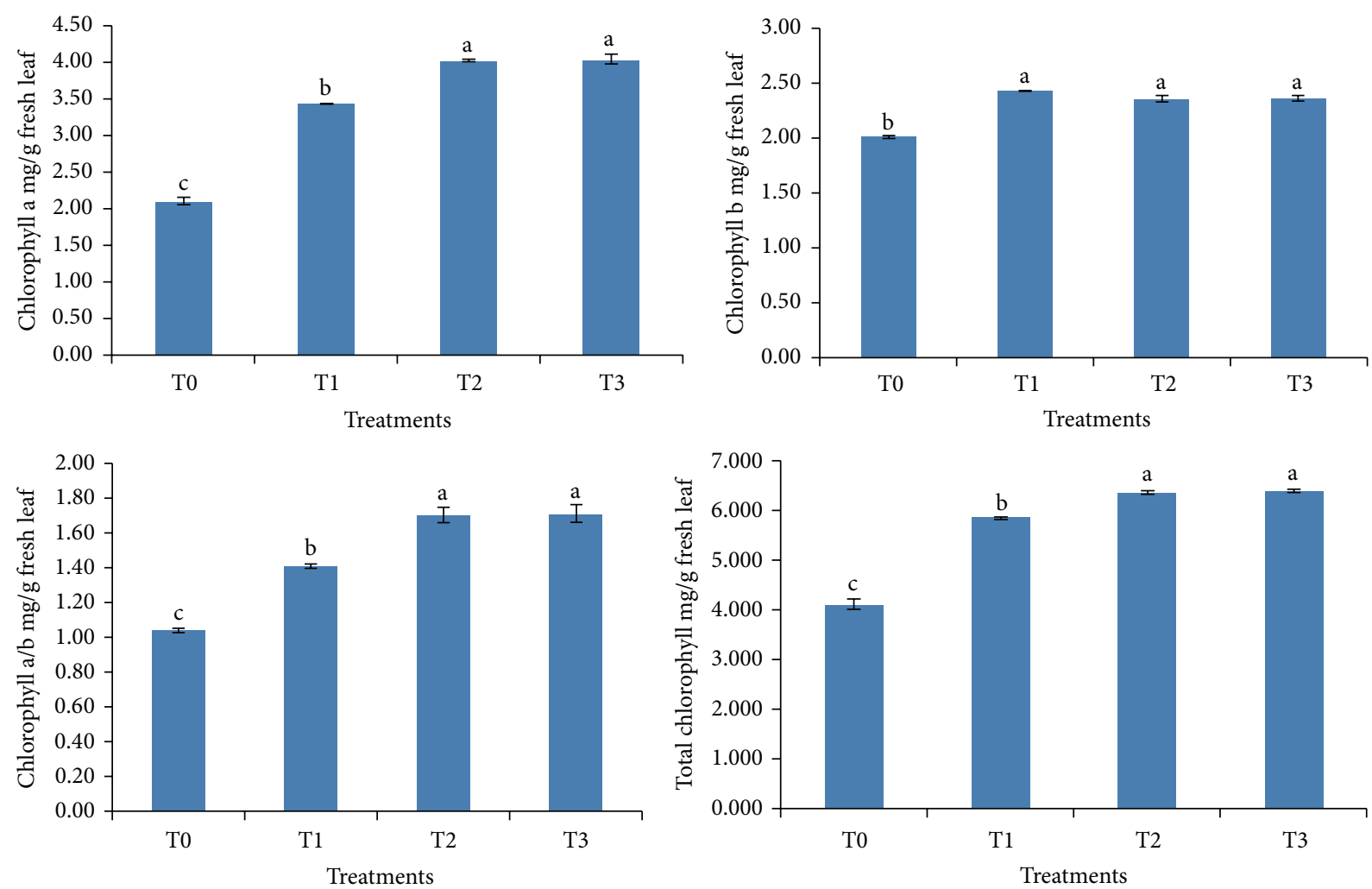

FIGURE 2: Effect of PGPR inoculation on chlorophyll content of okra leaves under salt stress. T0: noninoculated salt treated plants, T1: UPMR2 inoculated salt treated plants, T2: UPMR18 inoculated salt treated plants, and T3; both UPMR2 and UPMR18 inoculated salt treated plants. Error bars refer to standard error of means of four replicates. Means within columns with the same letters are not significantly different at $p<0.05$.

[47, 48]. Our results were consistent with the results of previous studies $[21,22]$. These studies demonstrated that increased salt concentrations decrease seed germination and root growth in dicotyledonous plants. In addition, germination of Limonium stocksii and Suaeda fruticosa seeds was inhibited with increasing $\mathrm{NaCl}$ concentrations [49]. In contrast, when the seeds were inoculated with the PGPR suspension, seed germination was reduced at a lower rate despite increasing salinity. This may indicate that the ACC deaminase-containing PGPR isolates, B. megaterium UPMR2 and Enterobacter sp. UPMR18, are able to ameliorate the effect of $\mathrm{NaCl}$ on growth medium. The PGPR got attached to the seed surface and synthesized phytohormones in response to amino acids produced by the seeds perhaps alleviating the salinity stress [50]. Our results were also supported by the findings of Jalili et al. [51] who demonstrated that the rate of germinating canola seeds (Brassica napus L.) inoculated with ACC deaminase-containing plant growth-promoting $P$. fluorescens and P. putida was significantly higher under salinity stress.

ACC deaminase-containing PGPR inoculated okra plants showed higher root and shoot biomass than noninoculated plants under salinity stress. This might be due to the presence of PGPR isolates in the growth medium, which alleviate the effects of salinity on okra plants by producing ACC deaminase. ACC deaminase-containing plant growthpromoting bacteria have been documented to facilitate the growth of a variety of plants under high salinity conditions 

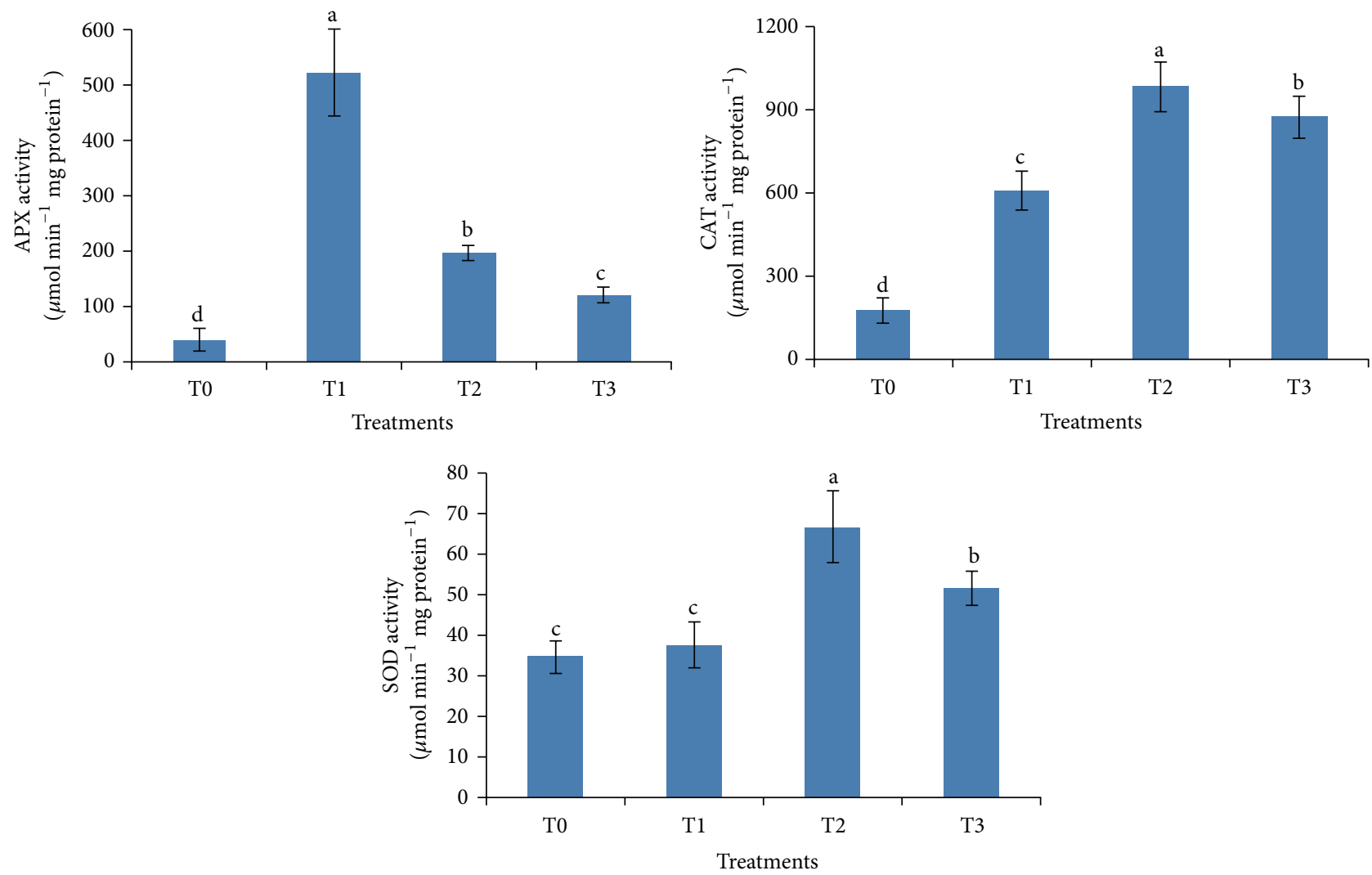

FIGURE 3: Effect of PGPR inoculation on antioxidant enzymes activities in okra leaves under salt stress. T0: noninoculated salt treated plants, T1: UPMR2 inoculated salt treated plants, T2: UPMR18 inoculated salt treated plants, and T3: both UPMR2 and UPMR18 inoculated salt treated plants. Error bars refer to standard error of means of four replicates. APX: ascorbate peroxidase, CAT: catalase, and SOD: superoxide dismutase. Means within columns with the same letters are not significantly different at $p<0.05$.

[52]. Cucumber plants inoculated with wild-type P. putida UW4 and Gigaspora rosea BEG9 showed significantly higher root and shoot fresh biomass than the plants that received ACC deaminase deficient bacteria and untreated control plants under $72 \mathrm{mM}$ salt stress [53]. When canola seeds were inoculated with ACC deaminase-containing salt tolerant bacteria under the $150 \mathrm{mM} \mathrm{NaCl}$ condition, the biomass of treated plants increased by up to $47 \%$ of the control plants [54]. Red pepper seedlings inoculated with ACC deaminasecontaining salt tolerant bacteria reduced 57\% stress ethylene production and produced similar amounts of biomass as to those in no salt treatment control plant [55].

Leaf chlorophyll concentration is an indicator of salt tolerance and responds to increasing salinity [56]. Chlorophyll content was significantly higher in okra plants receiving bacterial suspension compared with control plant. In control plants, chlorophyll is destroyed due to excessive amount of salts, ions ( $\mathrm{Na}$ and $\mathrm{Cl}$ ), or reactive oxygen species (ROS) which disturb the cellular metabolism and result in the degeneration of cell organelles in the leaf tissue $[57,58]$. On the other hand, the inoculated salt stressed okra plants exhibited higher chlorophyll content and dark green leaves owing to the presence of ACC deaminase-containing PGPR isolates that maintain the photosynthetic efficiency of plants by reducing ethylene biosynthesis. Ali and colleagues [27] observed that inoculation of plants with wild-type $P$. fluorescens YsS6 and P. migulae 8R6 significantly increased the total chlorophyll content of tomato plants compared with their ACC deaminase deficient mutants and control plants under salt stress. Higher chlorophyll content was also reported in ACC deaminase-containing PGPR inoculated salt stressed rice [59] and cucumber [60] compared to noninoculated plants.

Salinity stress leads to the formation of ROS, namely, superoxide $\left(\mathrm{O}_{2}{ }^{-}\right)$, singlet oxygen $\left(\mathrm{O}_{2}\right)$, hydroxyl $\left(\mathrm{OH}^{-}\right)$, and hydrogen peroxide $\left(\mathrm{H}_{2} \mathrm{O}_{2}\right)$, which cause severe damage to cell structures by exerting oxidation of cell membranes in a process known as oxidative stress [17, 61]. However, a defensive system called the antioxidant enzyme system is also activated under stress conditions. This system consists of several ROS-scavenging enzymes such as superoxide dismutase (SOD), peroxidase (POD), glutathione reductase (GR), monohydroascorbate reductase (MDHAR), ascorbate peroxidase (APX), and catalase (CAT). These antioxidant enzymes have the ability to remove the free radicals produced during abiotic stress conditions in the cell $[13,58,62]$. The okra plants inoculated with ACC deaminase-containing PGPR exhibited significant elevation of antioxidant enzyme activities (APX, CAT, and SOD) compared to noninoculated plants under saline conditions (Figure 3), thus confirming that PGPR 

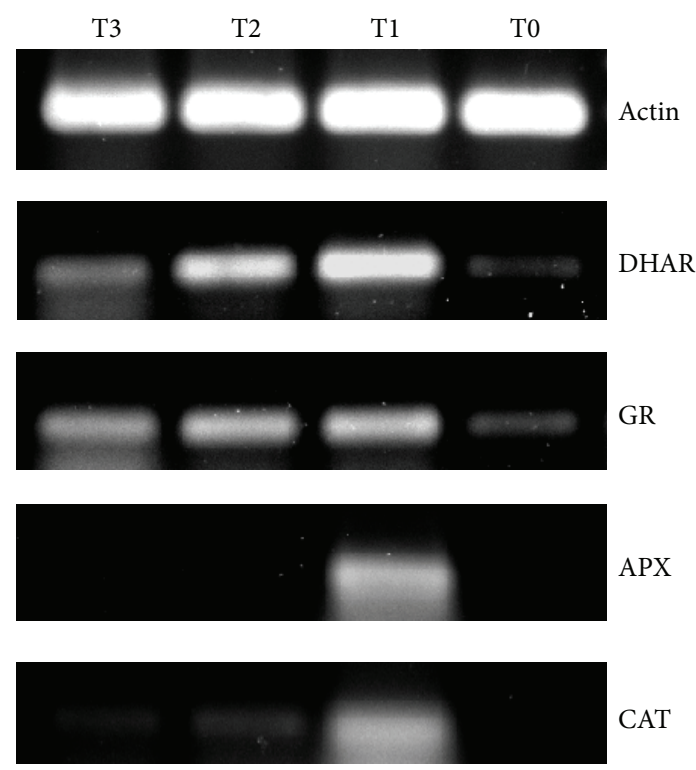

FIGURE 4: Effect of PGPR inoculation on DHAR, GR, APX, and CAT transcript levels by semiquantitative RT-PCR analysis of okra leaves under salt stress. T0: noninoculated salt treated plants, T1: UPMR2 inoculated salt treated plants, T2: UPMR18 inoculated salt treated plants, and T3: both UPMR2 and UPMR18 inoculated salt treated plants. Actin: positive control, APX: ascorbate peroxidase, CAT: catalase, GR: glutathione reductase, and DHAR: dehydroascorbate reductase.

inoculated plants were adapted to saline conditions by eliminating ROS through APX, CAT, and SOD activities. Our results are also supported by the findings of Gururani et al. [63], who reported enhanced activities of different ROSscavenging enzymes in PGPR inoculated potato plants under stress [63]. Moreover, in our study semiquantitative RT-PCR results (Figure 4) revealed that expression levels of different ROS pathway genes encoding CAT, APX, GR, and DHAR were increased in the ACC deaminase-containing PGPR treated salinized plants compared to the untreated controls. This result confirmed that the plants acquired protection from salt challenge as a consequence of PGPR inoculation. Our results were in agreement with the findings of Gururani et al. [63] who reported enhanced mRNA expression of different ROS pathway genes under salt, drought, and heavymetal stress in PGPR inoculated potato plants.

\section{Conclusion}

Little is known about enhanced salinity tolerance in okra due to ACC deaminase-containing PGPR. The current study showed that ACC deaminase-containing Enterobacter sp. UPMR18 emerged as the best treatment agent for enhancing seed germination and growth of okra seedlings under salinity stress. This may perhaps be due to a reduction in the growth inhibitory effect of salt on okra plants through the enhanced activity of antioxidant enzymes and expression of ROS pathway genes induced by the PGPR. Therefore, Enterobacter sp. UPMR18 could be used for okra cultivation in areas where salinity is a major constraint. However, further research is required to validate the effectiveness of this PGPR isolate, Enterobacter sp. UPMR18, in field conditions before recommendation for large scale okra cultivation at the agricultural level.

\section{Conflict of Interests}

The authors declare that there is no conflict of interests regarding the publication of this paper.

\section{Acknowledgment}

The authors thank the Universiti Putra Malaysia for financial and technical support through the research Grant "Geran (GP-IBT/2013/9407000) Universiti Putra Malaysia.”

\section{References}

[1] S. I. Allakhverdiev, A. Sakamoto, Y. Nishiyama, M. Inaba, and N. Murata, "Ionic and osmotic effects of NaCl-induced inactivation of photosystems I and II in Synechococcus sp.", Plant Physiology, vol. 123, no. 3, pp. 1047-1056, 2000.

[2] R. Munns, "Comparative physiology of salt and water stress," Plant, Cell \& Environment, vol. 25, no. 2, pp. 239-250, 2002.

[3] Z. Cheng, O. Z. Woody, B. J. McConkey, and B. R. Glick, "Combined effects of the plant growth-promoting bacterium Pseudomonas putida UW4 and salinity stress on the Brassica napus proteome," Applied Soil Ecology, vol. 61, pp. 255-263, 2012.

[4] W. B. Frommer, U. Ludewig, and D. Rentsch, "Taking transgenic plants with a pinch of salt," Science, vol. 285, no. 5431, pp. 12221223, 1999.

[5] F. N. Emuh, A. E. Ofuoku, and E. Oyefia, "Effect of intercropping okra (Hibiscus esclentus) with pumpkin (Curcubita maxima Dutch ex Lam) on some growth parameters and economic yield of maize (Zea mays) and maximization of land use in a fadama soil," Research Journal of Biological Sciences, vol. 1, no. 1-4, pp. 50-54, 2006.

[6] L. M. Dudley, A. Ben-Gal, and U. Shani, "Influence of plant, soil, and water on the leaching fraction," Vadose Zone Journal, vol. 7, no. 2, pp. 420-425, 2008.

[7] A. Cerdá, J. Pardines, M. A. Botella, and V. Martinez, "Effect of potassium on growth, water relations, and the inorganic and organic solute contents for two maize cultivars grown under saline conditions," Journal of Plant Nutrition, vol. 18, no. 4, pp. 839-851, 1995.

[8] H. M. Zadeh and M. B. Naeini, "Effects of salinity stress on the morphology and yield of two cultivars of canola (Brassica napus L.)," Journal of Agronomy, vol. 6, no. 3, pp. 409-414, 2007.

[9] M. R. Amirjani, "Effect of salinity stress on growth, mineral composition, proline content, antioxidant enzymes of soybean," American Journal of Plant Physiology, vol. 5, no. 6, pp. 350-360, 2010.

[10] A. Bybordi and E. Ebrahimian, "Effect of salinity stress on activity of enzymes involved in nitrogen and phosphorous metabolism case study: canola (Brassica napus L.)," Asian Journal of Agricultural Research, vol. 5, no. 3, pp. 208-214, 2011.

[11] J. Lloyd, P. E. Kriedemann, and D. Aspinall, "Comparative sensitivity of 'Prior Lisbon' lemon and 'Valencia' orange trees to foliar sodium and chloride concentrations," Plant, Cell \& Environment, vol. 12, no. 5, pp. 529-540, 1989. 
[12] C. A. Jaleel, K. Riadh, R. Gopi et al., "Antioxidant defense responses: physiological plasticity in higher plants under abiotic constraints," Acta Physiologiae Plantarum, vol. 31, no. 3, pp. 427436, 2009.

[13] R. Mittler, "Oxidative stress, antioxidants and stress tolerance," Trends in Plant Science, vol. 7, no. 9, pp. 405-410, 2002.

[14] J. Foreman, V. Demidchik, J. H. F. Bothwell et al., "Reactive oxygen species produced by NADPH oxidase regulate plant cell growth," Nature, vol. 422, no. 6930, pp. 442-446, 2003.

[15] J. F. Moran, E. K. James, M. C. Rubio, G. Sarath, R. V. Klucas, and M. Becana, "Functional characterization and expression of a cytosolic iron-superoxide dismutase from cowpea root nodules," Plant Physiology, vol. 133, no. 2, pp. 773-782, 2003.

[16] R. Santos, D. Hérouart, A. Puppo, and D. Touati, "Critical protective role of bacterial superoxide dismutase in Rhizobiumlegume symbiosis," Molecular Microbiology, vol. 38, no. 4, pp. 750-759, 2000.

[17] K. Apel and H. Hirt, "Reactive oxygen species: metabolism, oxidative stress, and signal transduction," Annual Review of Plant Biology, vol. 55, pp. 373-399, 2004.

[18] E. Sergeeva, S. Shah, and B. R. Glick, "Growth of transgenic canola (Brassica napus cv. Westar) expressing a bacterial 1aminocyclopropane-1-carboxylate (ACC) deaminase gene on high concentrations of salt," World Journal of Microbiology and Biotechnology, vol. 22, no. 3, pp. 277-282, 2006.

[19] H.-X. Zhang, J. N. Hodson, J. P. Williams, and E. Blumwald, "Engineering salt-tolerant Brassicaplants: characterization of yield and seed oil quality in transgenic plants with increased vacuolar sodium accumulation," Proceedings of the National Academy of Sciences of the United States of America, vol. 98, no. 22, pp. 12832-12836, 2001.

[20] S. Dobbelaere, J. Vanderleyden, and Y. Okon, "Plant growthpromoting effects of diazotrophs in the rhizosphere," Critical Reviews in Plant Sciences, vol. 22, no. 2, pp. 107-149, 2003.

[21] A. A. Belimov, V. I. Safronova, T. A. Sergeyeva et al., "Characterization of plant growth promoting rhizobacteria isolated from polluted soils and containing 1-aminocyclopropane-1carboxylate deaminase," Canadian Journal of Microbiology, vol. 47, no. 7, pp. 642-652, 2001.

[22] D. Saravanakumar and R. Samiyappan, "ACC deaminase from Pseudomonas fluorescens mediated saline resistance in groundnut (Arachis hypogea) plants," Journal of Applied Microbiology, vol. 102, no. 5, pp. 1283-1292, 2007.

[23] J. Yang, J. W. Kloepper, and C.-M. Ryu, "Rhizosphere bacteria help plants tolerate abiotic stress," Trends in Plant Science, vol. 14, no. 1, pp. 1-4, 2009.

[24] S. Mayak, T. Tirosh, and B. R. Glick, "Effect of wild-type and mutant plant growth-promoting rhizobacteria on the rooting of mung bean cuttings," Journal of Plant Growth Regulation, vol. 18, no. 2, pp. 49-53, 1999.

[25] B. R. Glick, C. B. Jacobson, M. K. Schwarze, and J. J. Pasternak, "1-Aminocyclopropane-1-carboxylic acid deaminase mutants of the plant growth promoting rhizobacterium Pseudomonas putida GR12-2 do not stimulate canola root elongation," Canadian Journal of Microbiology, vol. 40, no. 11, pp. 911-915, 1994.

[26] B. R. Glick, D. M. Penrose, and J. Li, "A model for the lowering of plant ethylene concentrations by plant growth-promoting bacteria," Journal of Theoretical Biology, vol. 190, no. 1, pp. 63-68, 1998.

[27] S. Ali, T. C. Charles, and B. R. Glick, "Amelioration of high salinity stress damage by plant growth-promoting bacterial endophytes that contain ACC deaminase," Plant Physiology and Biochemistry, vol. 80, pp. 160-167, 2014.

[28] M. Woitke, H. Junge, and W. H. Schnitzler, "Bacillus subtilis as growth promotor in hydroponically grown tomatoes under saline conditions," Acta Horticulturae, vol. 659, pp. 363-369, 2004.

[29] M. Becana, F. J. Paris, L. M. Sandalio, and L. A. Del Río, "Isoenzymes of superoxide dismutase in nodules of Phaseolus vulgaris L., Pisum sativum L., and Vigna unguiculata (L.) walp," Plant Physiology, vol. 90, no. 4, pp. 1286-1292, 1989.

[30] S. H. Habib, H. M. Saud, M. R. Ismail, and H. Kausar, "Bimolecular characterization of stress tolerant plant growth promoting rhizobacteria (PGPR) for growth enhancement of rice," International Journal of Agriculture and Biology, In press.

[31] C. B. Jacobson, J. J. Pasternak, and B. R. Glick, "Partial purification and characterization of 1-aminocyclopropane-1carboxylate deaminase from the plant growth promoting rhizobacterium Pseudomonas putida GR12-2," Canadian Journal of Microbiology, vol. 40, no. 12, pp. 1019-1025, 1994.

[32] K. Tamura, J. Dudley, M. Nei, and S. Kumar, "MEGA4: Molecular Evolutionary Genetics Analysis (MEGA) software version 4.0," Molecular Biology and Evolution, vol. 24, no. 8, pp. 15961599, 2007.

[33] M. A. Shahid, M. A. Pervez, R. M. Balal et al., "Salt stress effects on some morphological and physiological characteristics of okra (Abelmoschus esculentus L.)," Soil and Environment, vol. 30, no. 1, pp. 66-73, 2011.

[34] R. Moran and D. Porath, "Chlorophyll determination in intact tissues using N,N-dimethylformamide," Plant Physiology, vol. 65, no. 3, pp. 478-479, 1980.

[35] D. I. Arnon, "Copper enzymes in isolated chloroplasts. Polyphenol oxidase in Beta vulgaris," Plant Physiology, vol. 24, no. 1, pp. $1-15,1949$.

[36] M. M. Bradford, "A rapid and sensitive method for the quantitation of microgram quantities of protein utilizing the principle of protein-dye binding," Analytical Biochemistry, vol. 72, no. 1-2, pp. 248-254, 1976.

[37] C. N. Giannopolitis and S. K. Ries, "Superoxide dismutases: I. Occurrence in higher plants," Plant Physiology, vol. 59, no. 2, pp. 309-314, 1977.

[38] E. A. Havir and N. A. McHale, "Biochemical and developmental characterization of multiple forms of catalase in tobacco leaves," Plant Physiology, vol. 84, no. 2, pp. 450-455, 1987.

[39] G.-X. Chen and K. Asada, "Ascorbate peroxidase in tea leaves: occurrence of two isozymes and the differences in their enzymatic and molecular properties," Plant and Cell Physiology, vol. 30, no. 7, pp. 987-998, 1989.

[40] Hemavathi, C. P. Upadhyaya, N. Akula et al., "Biochemical analysis of enhanced tolerance in transgenic potato plants overexpressing d-galacturonic acid reductase gene in response to various abiotic stresses," Molecular Breeding, vol. 28, no. 1, pp. 105-115, 2011.

[41] F. B. Abeles, P. W. Morgan, and M. E. J. Salveit, Ethylene in Plant Biology, Academic Press, San Diego, Calif, USA, 2nd edition, 1992.

[42] J. C. Stearns and B. R. Glick, "Transgenic plants with altered ethylene biosynthesis or perception," Biotechnology Advances, vol. 21, no. 3, pp. 193-210, 2003.

[43] B. R. Glick, "Modulation of plant ethylene levels by the bacterial enzyme ACC deaminase," FEMS Microbiology Letters, vol. 251, no. 1, pp. 1-7, 2005. 
[44] S. Rashid, T. C. Charles, and B. R. Glick, "Isolation and characterization of new plant growth-promoting bacterial endophytes," Applied Soil Ecology, vol. 61, pp. 217-224, 2012.

[45] Y. Sun, Z. Cheng, and B. R. Glick, "The presence of a 1aminocyclopropane-1-carboxylate (ACC) deaminase deletion mutation alters the physiology of the endophytic plant growthpromoting bacterium Burkholderia phytofirmans PsJN," FEMS Microbiology Letters, vol. 296, no. 1, pp. 131-136, 2009.

[46] J. Kamaluldeen, I. A. M. Yunusa, A. Zerihun, J. J. Bruhl, and P. Kristiansen, "Uptake and distribution of ions reveal contrasting tolerance mechanisms for soil and water salinity in okra (Abelmoschus esculentus) and tomato (Solanum esculentum)," Agricultural Water Management, vol. 146, pp. 95-104, 2014.

[47] M. Jamil and E. H. Rha, "The effect of salinity (NaCI) on the germination and seedling of sugar beet (Beta vulgaris L.) and cabbage (Brassica oleracea L.)," Plant Resources, vol. 7, no. 3, pp. 226-232, 2004.

[48] M. Kafi and M. Goldani, "Effect of water potential and type of osmoticum on seed germination of three crop species of wheat, sugarbeet, and chickpea," Agricultural Sciences and Technology, vol. 15, no. 1, pp. 121-133, 2001.

[49] A. Hameed, A. Rasheed, B. Gul, and M. A. Khan, "Salinity inhibits seed germination of perennial halophytes Limonium stocksii and Suaeda fruticosa by reducing water uptake and ascorbate dependent antioxidant system," Environmental and Experimental Botany, vol. 107, pp. 32-38, 2014.

[50] C. L. Patten and B. R. Glick, "Role of Pseudomonas putida indoleacetic acid in development of the host plant root system," Applied and Environmental Microbiology, vol. 68, no. 8, pp. 3795-3801, 2002.

[51] F. Jalili, K. Khavazi, E. Pazira et al., "Isolation and characterization of ACC deaminase-producing fluorescent pseudomonads, to alleviate salinity stress on canola (Brassica napus L.) growth," Journal of Plant Physiology, vol. 166, no. 6, pp. 667-674, 2009.

[52] Z. A. Zahir, M. Arshad, and W. T. Frankenberger Jr., "Plant growth promoting rhizobacteria: applications and perspectives in agriculture," Advances in Agronomy, vol. 81, pp. 97-168, 2001.

[53] E. Gamalero, G. Berta, N. Massa, B. R. Glick, and G. Lingua, "Interactions between Pseudomonas putidaUW4 and Gigaspora rosea BEG9 and their consequences for the growth of cucumber under salt-stress conditions," Journal of Applied Microbiology, vol. 108, no. 1, pp. 236-235, 2010.

[54] M. A. Siddikee, P. S. Chauhan, R. Anandham, G.-H. Han, and T. Sa, "Isolation, characterization, and use for plant growth promotion under salt stress, of ACC deaminase-producing halotolerant bacteria derived from coastal soil," Journal of Microbiology and Biotechnology, vol. 20, no. 11, pp. 1577-1584, 2010.

[55] M. A. Siddikee, B. R. Glick, P. S. Chauhan, W. J. Yim, and T. Sa, "Enhancement of growth and salt tolerance of red pepper seedlings (Capsicum annuum L.) by regulating stress ethylene synthesis with halotolerant bacteria containing 1-aminocyclopropane-1-carboxylic acid deaminase activity," Plant Physiology and Biochemistry, vol. 49, no. 4, pp. 427-434, 2011.

[56] G. C. Percival, G. A. Fraser, and G. Oxenham, "Foliar salt tolerance of Acer genotypes using chlorophyll fluorescence," Journal of Arboriculture, vol. 29, no. 2, pp. 61-65, 2003.

[57] A. B. Hassine and S. Lutts, "Differential responses of saltbush Atriplex halimus L. exposed to salinity and water stress in relation to senescing hormones abscisic acid and ethylene," Journal of Plant Physiology, vol. 167, no. 17, pp. 1448-1456, 2010.
[58] T. Abbas, M. A. Pervez, C. M. Ayyub, and R. Ahmad, "Assessment of morphological, antioxidant, biochemical and ionic responses of salttolerant and salt-sensitive okra (Abelmoschus esculentus) under saline regime," Pakistan Journal of Life and Social Sciences, vol. 11, no. 2, pp. 147-153, 2013.

[59] H. B. Bal, L. Nayak, S. Das, and T. K. Adhya, "Isolation of ACC deaminase producing PGPR from rice rhizosphere and evaluating their plant growth promoting activity under salt stress," Plant and Soil, vol. 366, no. 1-2, pp. 93-105, 2013.

[60] S.-M. Kang, A. L. Khan, M. Waqas et al., "Plant growthpromoting rhizobacteria reduce adverse effects of salinity and osmotic stress by regulating phytohormones and antioxidants in Cucumis sativus," Journal of Plant Interactions, vol. 9, no. 1, pp. 673-682, 2014.

[61] S. Hussain, A. Khaliq, A. Matloob, M. A. Wahid, and I. Afzal, "Germination and growth response of three wheat cultivars to $\mathrm{NaCl}$ salinity," Soil \& Environment, vol. 32, no. 1, pp. 36-43, 2013.

[62] G. M. Abogadallah, "Differential regulation of photorespiratory gene expression by moderate and severe salt and drought stress in relation to oxidative stress," Plant Science, vol. 180, no. 3, pp. 540-547, 2011.

[63] M. A. Gururani, C. P. Upadhyaya, V. Baskar, J. Venkatesh, A. Nookaraju, and S. W. Park, "Plant growth-promoting rhizobacteria enhance abiotic stress tolerance in Solanum tuberosum through inducing changes in the expression of ROS-scavenging enzymes and improved photosynthetic performance," Journal of Plant Growth Regulation, vol. 32, no. 2, pp. 245-258, 2013. 

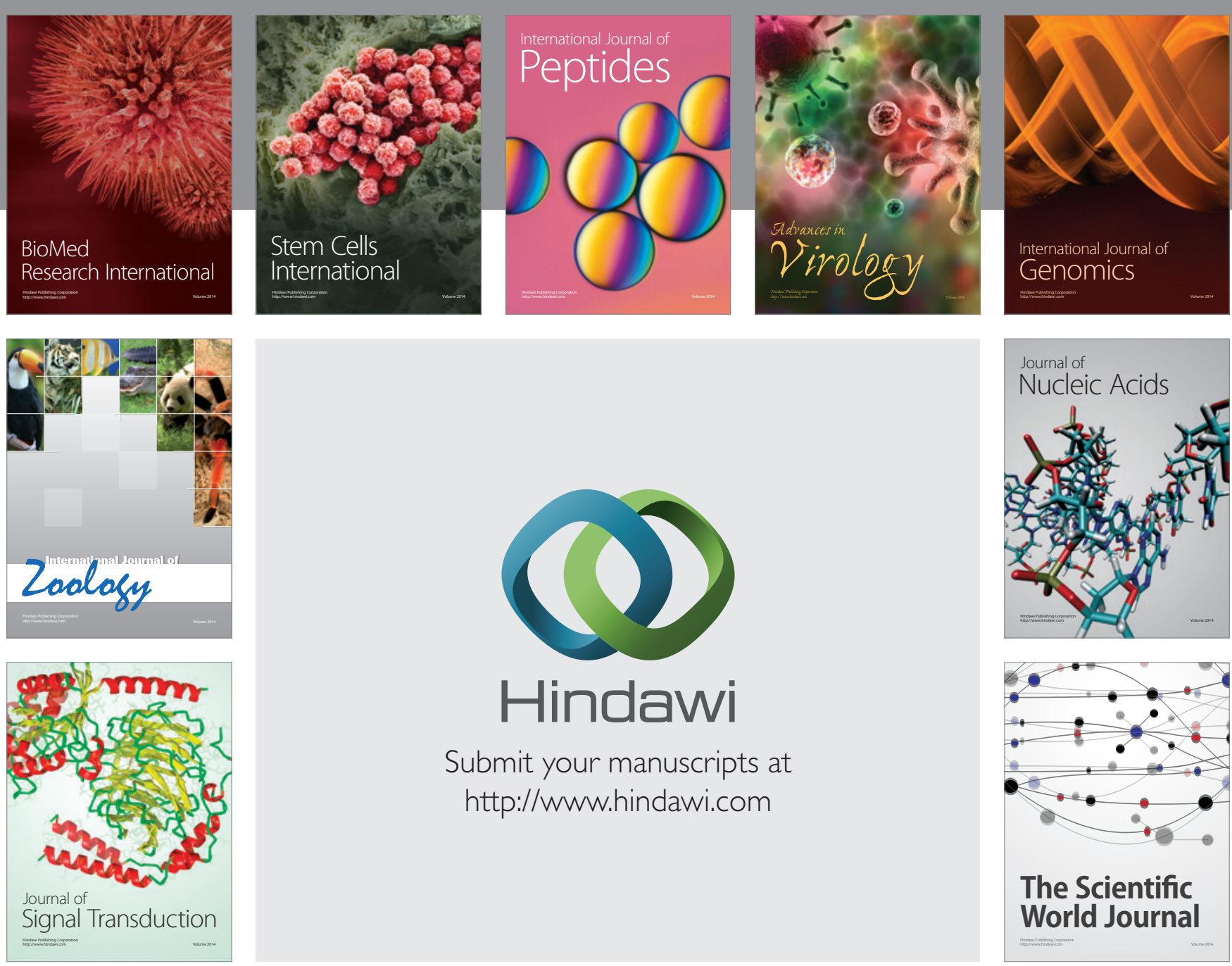

Submit your manuscripts at

http://www.hindawi.com
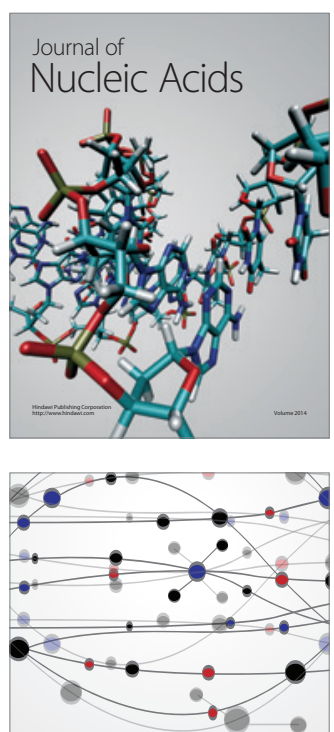

The Scientific World Journal
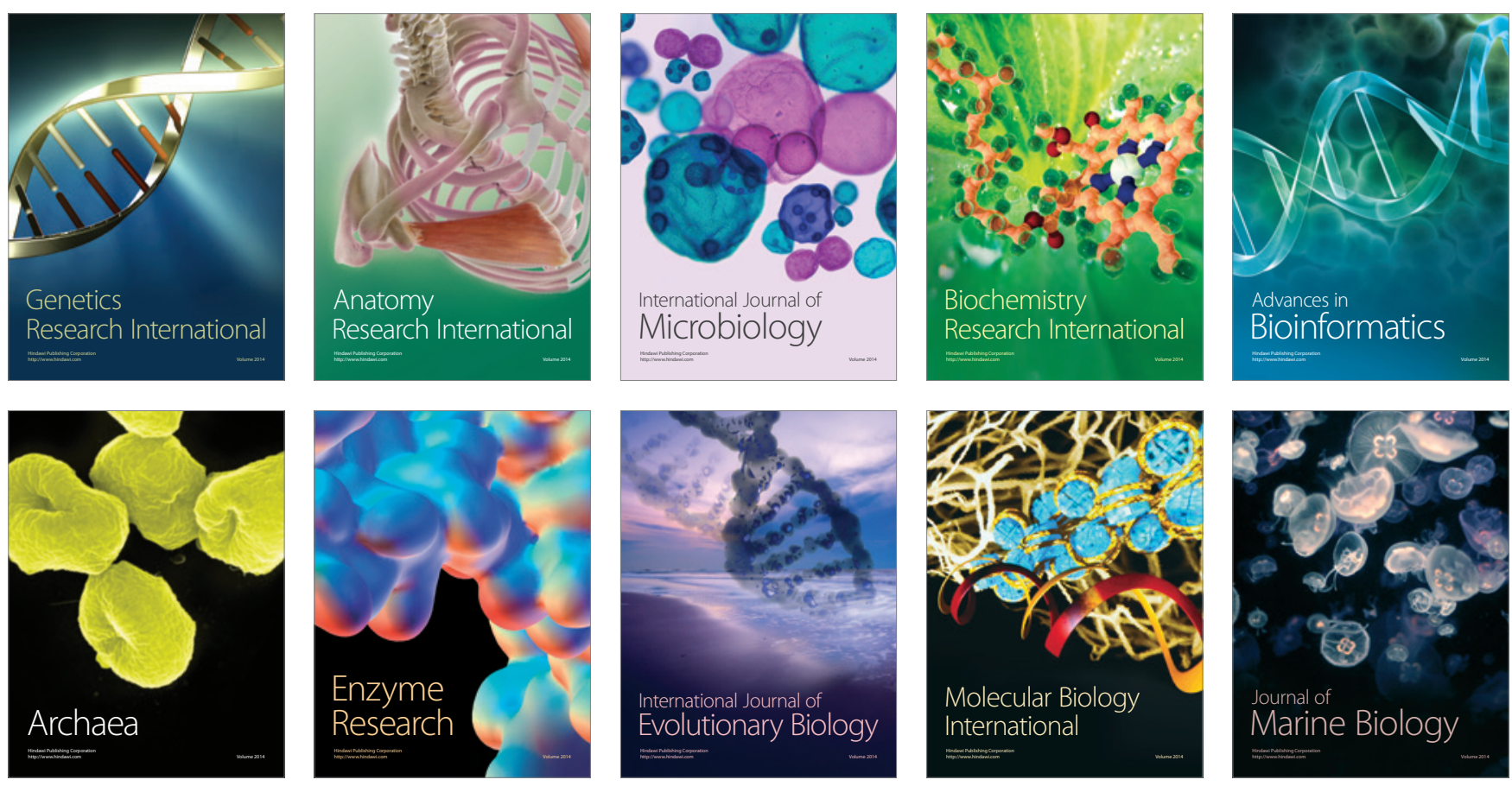